\title{
Role of Plant Based Lectins in Identifying Rare Bombay Blood Group
}

\author{
Raj Bharath Rudrappan* and Krishnan Veeran \\ Department of Plant Biology and Plant Biotechnology, Presidency College, Chennai 600005, Tamil Nadu, India.
}

\begin{abstract}
Background: Lectins are proteins found in a diversity of plants and organisms. They possess the ability to agglutinate erythrocytes with known carbohydrate specificity. Methods: A lectin named Anti $\mathrm{H}$ is used in identification of a very rare and important blood group named Bombay blood group is extracted from the plant Ulex europaeus. Our study was done to calculate the prevalence of Bombay blood group in our Indian population using the plant based extract lectin anti $\mathrm{H}$. Blood grouping was done using the tube technique using commercially available antisera. Results: Out of the total 11,512 blood samples collected and analysed, two samples were identified to be Bombay blood group. The prevalence of Bombay blood group in our study is $.017 \%$. The prevalence of the Bombay blood group varied slightly among different regions in parts of India. Conclusion: Anti $\mathrm{H}$ Lectin helped in identifying Bombay Blood Group which would otherwise
\end{abstract}

have been missed in routine blood grouping. Plant based lectins will perform an important role in the field of transfusion medicine in near future.

Key words: Ulex europaeus, Bombay phenotype, Lectin, Blood grouping, $\mathrm{H}$ antigen.

Address for Correspondence:

Dr. Raj Bharath Rudrappan, Research Scholar, Department of Plant Biology and Plant Biotechnology, Presidency College, University of Madras, New No. 53, Singarachari Street, Triplicane, Chennai-600005, India.

Phone no: 9444338316

E-mail: Rajrr.84@gmail.com

DOI : 10.5530/pj.2016.1.15

\section{INTRODUCTION}

Lectins are unique proteins of varying biological importance. They are characterized by specific binding to carbohydrate residues. ${ }^{1}$ Lectins are an important tool in the identification of different blood groups. Each Lectins produced from the plants have specific blood group activity such as Dolichos biflorus (anti-A1), Ulex europaeus (anti-H) and Vicia graminea (anti-N) and can be used as an alternative to commercial antisera. $^{2}$

One of the lectin used in identification of a very rare and important blood group is extracted from the plant Ulex europaeus. The lectin based reagent is called anti $\mathrm{H}$ and is used to identify Bombay blood group (the blood group was identified in Bombay i.e Mumbai).

Bombay blood group is an extremely rare autosomal recessive Phenotype characterized by the absence of $\mathrm{H}, \mathrm{A}$ and $\mathrm{B}$ antigens on red cells and in secretions. Genetically $\mathrm{O}_{h}$ individuals are homozygous for nonfunctional $\mathrm{H}(\mathrm{hh}$ ) and secretor (sese) genes resulting in a complete absence of type 1 and type 2 chain $\mathrm{H}, \mathrm{A}$ and $\mathrm{B} .{ }^{3}$ Bombay phenotype $\left(\mathrm{O}_{\mathrm{h}}\right.$ or hh) was first identified in 1952 by Dr. Y. M. Bhende. ${ }^{4}$ Bombay Blood Group is extremely rare with an estimated prevalence of 1:10,000 individuals in India and about 1: 1,000,000 persons in other parts of the world. ${ }^{5}$

Persons with the Bombay phenotype have strong anti-H in their plasma and if they are transfused blood group $\mathrm{O}$ red cells or any other blood group red cells, they may develop an acute hemolytic transfusion reaction which can be fatal to the transfused recepient. ${ }^{6}$

Our study was done to calculate the prevalence of Bombay blood group in our Indian population using the plant based extract lectin anti $\mathrm{H}$.

\section{MATERIALS AND METHODS}

The blood samples were collected from 11,512 people and blood grouping was done using tube technique. Our study population was people in Pondicherry and Villupuram district, Tamilnadu. Forward grouping was done with freshly prepared 5\% red cell suspension from the blood sample collected against commercially obtained Anti A, Anti B, Anti D sera (Tulip Diagnostics). Reverse grouping was done using A, B and O pooled cells (prepared in-house) against the serum of the blood sample. Anti $\mathrm{H}$ lectin which was commercially obtained (Tulip Diagnostics) was used to find out the presence of $\mathrm{H}$ antigen in the blood.

\section{RESULTS}

The total number of blood samples tested was 11,512. Out of the total samples, only two samples were identified to be Bombay blood group. The two samples agglutinated all the A, B and $\mathrm{O}$ pooled cells in the reverse grouping due to the presence of anti $\mathrm{A}$, anti $\mathrm{B}$ and anti $\mathrm{H}$ in the serum. On testing with anti $\mathrm{H}$ with the red cells of the collected sample, there was no agglutination indicating the absence of $\mathrm{H}$ antigen.

\section{DISCUSSION}

Lectins possess the ability to agglutinate erythrocytes with known carbohydrate specificity since they have at least one non-catalytic domain that binds reversibly to specific monosaccharides or oligosaccharides. Lectins with specific carbohydrate specificity have been purified from various plant tissues and other organisms. They can be classified on the basis of their carbohydrate specificity. ${ }^{7}$

This anti $\mathrm{H}$ lectin extracted from the plant Ulex europaeus agglutinate a specific substance named Fucose. This Fucose is the basis for formation of $\mathrm{H}$ antigen. The $\mathrm{H}$ antigen is the precursor of all the blood group antigens and persons with the rare Bombay phenotype (hh) do not express $\mathrm{H}$ antigen. The serum of such individuals has strong anti-H as well as anti$A$ and anti-B. If patients with Bombay phenotype receive transfusions of blood that contains the $\mathrm{H}$ antigen (e.g., blood group $\mathrm{O}$ ), they are at risk of suffering an acute hemolytic transfusion reaction. Since their red cells do not react with anti- $\mathrm{A}$, anti-B and anti- $\mathrm{AB}$ antiseras, they are wrongly identified as the $\mathrm{O}$ blood group in cell typing. ${ }^{8}$ Persons with Bombay blood group can only be transfused by autologous blood or blood from individuals of Bombay $\mathrm{O}_{\mathrm{h}}$ phenotype. ${ }^{9}$

The prevalence of Bombay blood group in our study is .017\% which was similar to study conducted by Talukder et al., (2014). ${ }^{10}$ Das et al (2001) 
in his study based in south india estimated the prevalence was $0.004 \%$ while Verma et al (2011)in his study in Andhra found the prevalence $0.048 \%{ }^{11-12}$ Similar study done in other parts of india reported the prevalence was around $0.005 \% .{ }^{13}$ Study done by Balgir et al (2007) among tribal populations in Orissa who reported a higher prevalence in the Bombay blood group attributed the increase due to consanguineous marriage among the population. ${ }^{14}$ Since the gene for Bombay phenotype is a recessive gene, the transmission of the gene occurs more frequently in case of a consanguineous marriage.

There are also variants in Bombay blood group like the Para -Bombay Phenotype which can also cause severe transfusion reactions if blood from other blood groups is transfused.$^{15}$ Identification of Bombay blood phenotype will also help in identifying certain rare congenital anomalectins are excellent reagents because of their lower cost and indigenous production. ${ }^{16}$

\section{CONCLUSION}

Anti $\mathrm{H}$ lectin extracted from the plant Ulex europaeus perform an important role in identifying the rare Bombay phenotype. Misidentification of the Bombay phenotype has resulted in wrong blood being transfused and leading to severe transfusion reactions. There is still a lot of potential for the other plant based lectins to be actively used in the field of transfusion medicine.

\section{ACKNOWLEDGEMENTS}

The authors wish to express their gratitude to the staffs and management of Sri Manakula Vinayagar Medical College And Hospital, Pondicherry.

\section{CONFILCTS OF INTEREST}

The authors declare no conflict of interest.

\section{ABBREVIATION USED}

$\mathbf{O}_{\mathbf{h}}$ : Bombay Phenotype, BBG: Bombay Blood Group, hh: Recessive genotype in Bombay blood group. lies associated with the absence of $\mathrm{H}$ antigen. Besides their specificity,

\section{REFERENCES}

1. Khan F, Khan RH, Sherwani $A$, Mohmood $S$, Azfer MA. Lectins as markers for blood grouping. Medical Science Monitor. 2002; 8(12): RA293-300

2. Judd WJ. The role of lectins in blood group serology. Critical Review in Clinical Laboratory Science. 1980; 12(3): 171-214.

3. Laura Cooling. ABO, $\mathrm{H}$ and Lewis Blood Groups and structurally Related Antigens. In: American Association of Blood Banks, Technical Manual., 17th edt, p-375.

4. Bhende YM, Deshpande CK, Bhatia HM. A new bloodgroup character related to the ABO system. Lancet 1952; 1(6714): 903-4.

5. Oriol R, Candelier JJ, Mollicone R. Molecular genetics of H. Vox Sanguinis 2000;78:105-8.

6. Shahshahani HJ, Vahidfar MR, Khodaie SA. Transfusion reaction in a case with the rare Bombay blood group. Asian Journal of Transfusion Science 2013; 7(1): 86-7.

7. Sze Kwan Lam \& Tzi Bun Ng. Lectins: production and practical applications. Applied Microbiology and Biotechnology 2011; 89(1): 45-55

8. Shrivastava M, Navaid S, Peethambarakshan A, Agrawal K, Khan A. Detection of rare blood group, Bombay $\left(O_{h}\right)$ phenotype patients and management by acute normovolemic hemodilution. Asian Journal of Transfusion Science 2015 9(1):74-7.

9. Nirmala Jonnavithula, Shanthi Bonagiri, Gopinath Ramachandran, RC Mishra Peri-operative red cell transfusion management in a H-deficient (Para Bombay) blood group variant. Indain journal of anaesthesia 2013; 57(1): 78-9.

10. Biplabendu Talukder, Suvro Sankha Datta, Somnath Mukherjee, Krisnendu Mukherjee. Prevalence of Bombay Group Blood in Southern Bengal Population. Indian Journal of Hematology and Blood Transfusion 2014; 30(3): 149.

11. Das PK, Nair SC, Harris VK, Rose D, Mammen JJ, Bose YN, et al. Distribution of $\mathrm{ABO}$ and Rh-D blood groups among blood donors in a tertiary care centre in South India. Trop Doct 2001; 31(1): 47-8.

12. Verma A, Vani KG, Chaitanya Kumar IS, Jothi Bai DS. Prevalence of Bombay blood group in a tertiary care hospital, Andhra Pradesh, India. Asian Journal of Transfusion Science 2011; 5(1): 57-8.

13. Periyavan S, Sangeetha SK, Marimuthu P, Manjunath BK, Seema DM. Distribution of $A B O$ and Rhesus-D blood groups in and around Bangalore. Asian Journal of Transfusion Science 2010; 4(1): 41.

14. Balgir RS. Identification of a rare blood group, "Bombay $\left(\mathrm{O}_{h}\right)$ phenotype," in Bhuyan tribe of Northwestern Orissa, India. Indian Journal of Human Genetics 2007; 13(3): 109-13.

15. Fereidoon Ala md. another case of para-bombay phenotype inan iranian donor Archives of Iranian Medicine. 2004; 7(4): 284-6.

16. Priya Subashchandrabose, Vasudevan Kasturirengan, Monica Vincent Bonipace, Sarada Venkatesan. blood group in a female child with congenital anomalies and recurrent infections-a rare case report. International journal of recent Trends in Science and Technology October 2014; 12(3): 617-9.

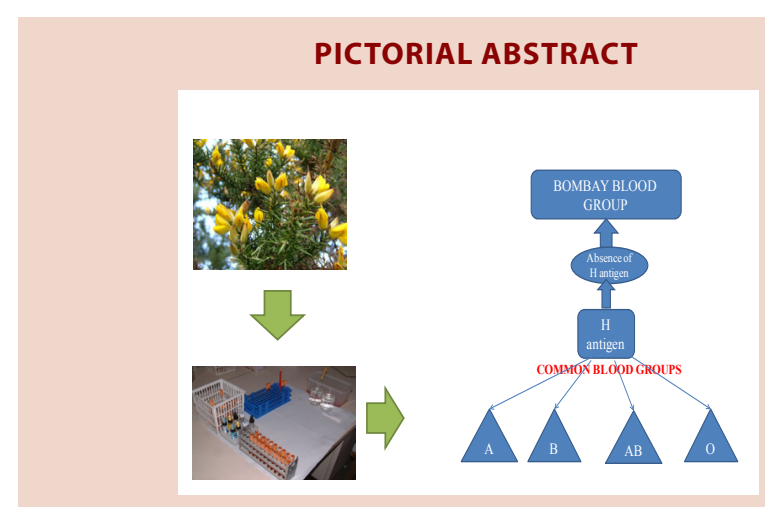

\section{SUMMARY}

- Anti H Lectin prepared from the plant Ulex europaeus was used to identify Bombay blood group

- Two blood samples tested with anti H did not agglutinate confirming the presence of Bombay Phenotype

- The prevalence of Bombay blood group in our study was $0.017 \%$

- Misidentification of Bombay phenotype can result in severe adverse transfusion reaction which was avoided by testing with anti $\mathrm{H}$ lectin.

\section{ABOUT AUTHORS}

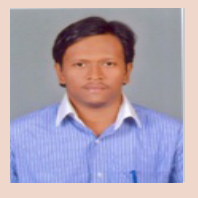

R. Raj Bharath: Is a research scholar at the University of Madras. He is working as Assistant professor at Department of Transfusion Medicine, The Tamilnadu Dr. M.G.R University. He had finished his M.B.B.S and M.D in Transfusion Medicine. His areas of interest are Plant Biology, Pharmacognosy and Immunohematology. He is a member of Indian Society of Blood Transfusion and Immunohematology and Indian Society of Transfusion Medicine.

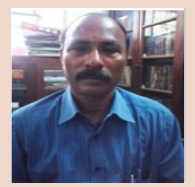

V. Krishnan: Is working as Assistant Professor of Botany, Presidenc college, University of Madras. His areas of specialization include Plant Taxonomy and Plant Anatomy. He is a member of Indian Botanical Congress. He has published articles in various national and international journals and presented papers in various conferences. 